\title{
Effects of a dual-purpose bacterial inoculant on the fermentation characteristics of high-moisture maize silage and dairy cattle performance
}

\author{
H. Mohammadzadeh ${ }^{1 \#}$, M. Khorvash ${ }^{1}$, G.R. Ghorbani ${ }^{1}$ \& W.Z. Yang $^{2}$ \\ ${ }^{1}$ Department of Animal Science, Faculty of Agriculture, Isfahan University of Technology, 84156-83111, Isfahan, Iran; \\ ${ }^{2}$ Agriculture and Agri-Food Canada, Research Centre, Lethbridge, AB, T1J 4B1, Canada
Copyright resides with the authors in terms of the Creative Commons Attribution 2.5 South African Licence. See: http://creativecommons.org/licenses/by/2.5/za
Condition of use: The user may copy, distribute, transmit and adapt the work, but must recognise the authors and the South African Journal of Animal Science.

\begin{abstract}
The objective of this study was to investigate the effects of inoculating Lactisil Maize, a dual-purpose inoculant, on the fermentation characteristics and nutritive value of high-moisture maize silage and the performance of lactating cows receiving the silage in their diets. Whole-crop maize was harvested at $253 \mathrm{~g}$ dry matter (DM)/kg fresh crop. Maize silage was produced with or without Lactisil Maize and ensiled in two different bunkers. Eight multiparous lactating Holstein dairy cows were used in a replicated $2 \times 2$ Latin square experimental design and were fed total mixed rations that contained $230 \mathrm{~g} / \mathrm{kg}$ of either inoculated or control maize silage. Inoculation did not affect the nutritive value or the aerobic stability of the maize silage, but increased the neutral detergent and acid detergent fibre fractions of the silage. However, inoculation increased the concentrations of acetic acid and lactic acid, but reduced ammonia $\mathrm{N}$ concentration compared to the control. Cows fed the Lactisil Maize-inoculated silage had a lower DM intake, milk yield, and yields of milk fat and milk protein were lower, compared to control. The digestibility of nutrients was not affected by inoculation. It was concluded that although Lactisil Maize inoculation improved the fermentation quality of high-moisture maize silage, it did not improve aerobic stability of the silage or the production performance of dairy cows compared to the control.
\end{abstract}

Keywords: Low dry matter, aerobic stability, Lactobacillus buchneri, Lactobacillus plantarum, anaerobic fermentation, nutrient digestibility

${ }^{\#}$ Corresponding author: hamidmhz@ag.iut.ac.ir

\section{Introduction}

Ensiling is a common preservation method for moist forage crops. It is based on the anaerobic fermentation of water-soluble carbohydrates (WSC) into lactic acid and volatile fatty acids (VFA) by lactic acid bacteria (LAB). Maize is one of the major forages used for ensiling due to its excellent nutritional quality and good ensiling properties (Allen et al., 2003). Maize silage is used as a source of effective fibre and fermentable energy that makes up to $50 \%$ of the forage source in the rations of dairy cows in many commercial dairies in the world and in Iran (NRC, 2001; Kowsar et al., 2008). However, maize crops grown in Iran are usually planted in July as a second crop. Therefore, it does not get sufficient time to mature and is ensiled with a low dry matter (DM) (20 to $25 \%$ ) content (Khorvash et al., 2006). Moreover, after opening the silo for feeding, exposure to oxygen leads to aerobic deterioration of the silage. Maize silages are susceptible to spoilage because of higher concentrations of lactic acid and WSC (McDonald et al., 1991). This condition forces farmers to improve their management during crop harvesting and ensiling, e.g. using various types of silage additives including bacterial inoculants. The biological additives for silages are safe and easy to use, noncorrosive to machinery, do not pollute the environment and are regarded as natural products (Filya et al., 2000). During the last two decades, many microbial inoculants have been developed in order to improve the ensiling process and silage quality. Homofermentative and heterofermentative LAB inoculants are two types 
of inoculants commonly used in silage production. Homofermentative LAB such as Lactobacillus plantarum, generally increases lactic acid and decreases acetic acid, butyric acid and ammonia-nitrogen $\left(\mathrm{NH}_{3}-\mathrm{N}\right)$ levels, and the $\mathrm{pH}$ of the silage (Sheperd et al., 1995; Aksu et al., 2004). However, homofermentative LAB often increases aerobic deterioration of whole-crop cereal silages, probably because of insufficient VFAs to inhibit fungal growth (Weinberg et al., 1993; Filya et al., 2000; Kleinschmit \& Kung, 2006b).

Heterofermentative LAB usually improves the aerobic stability of silage (Driehuis et al., 1999; Filya, 2001; Kung \& Ranjit, 2001; Weinberg et al., 2002; Filya, 2003b). Lactobacillus buchneri is the main heterofermentative LAB inoculant most widely used during the ensiling of forages (Muck, 2008). Due to the fact that L. buchneri cannot be found in high quantities in most forages (Torriani et al., 1992), isolates of this bacterium have been identified and developed into silage inoculants (Muck, 1996). In recent years, dualpurpose inoculants have been developed to enhance both the efficiency of anaerobic fermentation and to improve aerobic stability (Hu et al., 2009). Lactisil Maize, a new commercial multi-species bacterial inoculant, consists of homofermentative (Enterococcus faecium M74, L. plantarum LS1, Lactobacillus casei and Pediococcus pentosaceus) and heterofermentative LAB (L. buchneri). For optimal fermentation, E. faecium and $P$. pentosaceus require a relatively high $\mathrm{pH}$ and, thus, start to produce lactate at a high $\mathrm{pH}$ in forage crops. This leads to a faster decrease in $\mathrm{pH}$ which provides better environmental conditions for $L$. plantarum and $L$. casei who require a lower $\mathrm{pH}$ for optimal fermentation. In the later phase of silage production, L. buchneri starts to produce acetic acid, resulting in an increase in aerobic stability of silages. The aim of the current study was to investigate the effects of Lactisil Maize on the chemical composition and fermentation characteristics of high-moisture maize silage and on the performance of lactating dairy cows.

\section{Materials and Methods}

Whole-crop maize (hybrid 700; Plant Breeding, Karaj, Iran) was harvested at $253 \mathrm{~g} \mathrm{DM} / \mathrm{kg}$ of fresh crop, and chopped to theoretical length of $2.5 \mathrm{~cm}$, using a pool-type chopper (Model 965, Claas, Omaha, Netherland). The maize silage was produced with or without an inoculant, and treatments were the control (no inoculant) and inoculation with Lactisil Maize (Medipharm, Kågeröd, Sweden). Two bunker silos (with about $300 \mathrm{t}$ capacity for fresh maize crops) were filled with the chopped maize, one with the inoculant, the other with inoculant-free water. The inoculant was applied layer by layer as the crop was unloaded from the silage wagon into the silos, followed by heavy rolling during the packing process. For each $50 \mathrm{t}$ of crop, 500 $\mathrm{g}$ of inoculant was diluted into $200 \mathrm{~L}$ of water and sprayed over the freshly-chopped maize to obtain at least $1.5 \times 10^{5}$ colony-forming units (cfu) per g of fresh forage. For the control treatment, the same amount of inoculant-free water was applied. After 230 days of ensiling, both silos were opened and the silages were analyzed for chemical composition (Table 1) and fed to dairy cattle.

Eight multiparous, lactating Holstein cows $(107 \pm 15 \mathrm{~d}$ in milk and producing $41.8 \pm 3 \mathrm{~kg}$ milk/d) were used in a replicated $2 \times 2$ Latin square experimental design with one of the two diets. The cows were allocated to squares based on days in milk, and randomly assigned to treatments within a square. They were offered the diets (Table 2) twice daily at 09:00 and 16:00 at a level to allow a maximum of 10\% refusals. Diets were formulated based on the NRC (2001) recommendations to supply sufficient energy and protein for a $600 \mathrm{~kg}$ cow producing $40 \mathrm{~kg} / \mathrm{d}$ of milk, containing 3.5\% fat and $3.2 \%$ protein. The cows were housed in individual stalls at the dairy facilities of the Lavark Research Station (Isfahan University of Technology, Isfahan, Iran). The experiment consists of two periods of 21 days; the first 14 days for adaptation and the last 7 days for sampling and data collection. The individual stalls $(4 \times 4 \mathrm{~m})$ were equipped with concrete feed bunkers. The cows had ad libitum access to fresh water and a salt block. Clean wood shavings and sand were used as bedding and replaced twice a day. The animals were handled according to the guidelines of the Iranian Council of Animal Care (1995) at the Dairy Facilities of the Lavark Research Station.

After 230 days of ensiling, about $15 \mathrm{~kg}$ of the silage was sampled at six sites from each silo, and was thoroughly mixed to obtain a representative sample of $c a .3 \mathrm{~kg}$. About half of this sample was used for the determination of aerobic stability and the other half was frozen until further analysis for biochemical characteristics could be completed. At the beginning of each experimental period, the DM content of maize silages was determined prior to diet formulation.

The cows were milked three times daily in a milking parlour at 04:00, 12:00, and 20:00, with no provision of water or concentrate during milking. At the 12:00 milking session, the cows were allowed a 30 min exercise period outside, before being milked. During the last five days of sampling, the milk yield of all 
cows was recorded. The milk yield of each cow at each milking session, was measured using special graduated jars (Agri \& SD Co., Frankfurt, Germany). Before each milking session, the cows were monitored for udder inflammation and the presence of milk clots in the nipples to ensure that the milk yield and composition were not affected by mastitis. Milk from individual cows was sampled at each milking session in pre-labelled $50 \mathrm{~mL}$ plastic vials and preserved with potassium dichromate until it could be analyzed for milk components.

Samples of the diets and orts were collected during days $14-21$ of each period. The feed intake was calculated as the difference between feed offered and orts collected. Grab faecal samples were taken daily from the rectum during data collection. The daily collected orts and faeces from each cow were composited. Feeds, orts and faecal samples were stored at $-20{ }^{\circ} \mathrm{C}$ pending chemical analysis. Body weights were recorded on days 19 to 21 of each period at the same time each day.

On the last day of each period, rumen fluid was sampled at $4 \mathrm{~h}$ post-feeding to monitor rumen fermentation, by using a stomach tube. The initial $400 \mathrm{~mL}$ of the fluid aspirated was discarded to minimize saliva contamination. The $\mathrm{pH}$ of the second portion was measured immediately, using a mobile $\mathrm{pH}$ meter (HI8314, Hanna Instruments, ClujNapoca, Romania), and $10 \mathrm{~mL}$ of the fluid was preserved with $1 \mathrm{~mL}$ of $5 \%$ sulphuric acid and frozen at $-20{ }^{\circ} \mathrm{C}$ for VFA analysis.

The analysis on the pre-ensiled maize, silage, feeds, orts and faecal samples were done in triplicate. Dry matter was determined in a drying oven for $72 \mathrm{~h}$ at $60{ }^{\circ} \mathrm{C}$. The dried samples were ground to pass through a $1 \mathrm{~mm}$ screen using a Wiley mill (Arthur H. Thomas Co., Philadelphia). Organic matter was determined by incinerating the material at $550{ }^{\circ} \mathrm{C}$ for $12 \mathrm{~h}$. Total nitrogen $(\mathrm{N})$ was determined by using the Kjeldahl method (Kjeltec 1030 Auto Analyzer, Tecator, Höganäs, Sweden). Neutral detergent fibre (NDF) was determined according to the method of Van Soest et al. (1991) and the concentration of acid detergent fibre (ADF) as described by AOAC (1990).

Twenty gram of fresh maize or maize silage was mixed with $180 \mathrm{~mL}$ distilled water and blended for $30 \mathrm{~s}$ in a blender (GS253-450, Sunny, China). This was filtered through two No. 1 filter papers (Whatman, Maidstone, U.K.) to obtain the extract which was used to measure the organic acid and ammonia-N $\left(\mathrm{NH}_{3}-\mathrm{N}\right)$ concentrations in the silage extracts (Filya, 2003a). Immediately after extraction, the $\mathrm{pH}$ was measured, using a portable $\mathrm{pH}$ meter (HI8314, Hanna Instruments, ClujNapoca, Romania). Ammonia-N concentration was measured by distillation in a Kjeldahl auto analyzer (Filya, 2003a). Volatile fatty acid concentrations in the silage extract and in ruminal fluid were determined by using gas chromatography (WCOT Fused Silica Capillary, CHROMPACK CP. 9002, Model No. CP-9002, Serial No. 9477 B, Vulcanusweg 259, AM DELFT, the Netherlands). Lactic acid was determined according to the technique of Barker \& Summerson (1941) and WSC, using the phenol-sulphuric acid method of Dubois et al. (1956).

Milk samples were analyzed for lactose, fat and protein on a Milk-O-Scan (134 BN Foss Electric, Hillerod, Denmark). The milk composition was calculated as the average of the triple samples, using the portion of daily production at milking time as a weighting factor (Bal et al., 2000). Acid detergent insoluble ash (ADIA) concentration was measured in the composited diet and faecal samples, and used as an internal marker to calculate the apparent total-tract digestibility of the nutrients (Nikkhah et al., 2004).

Aerobic stability was defined as the number of hours that it took the silage to rise $2{ }^{\circ} \mathrm{C}$ above that of the ambient temperature, as described by Nishino et al. (2003). After opening the silos, about $1500 \mathrm{~g}$ of silage samples were loosely packed in open plastic containers, and a thermometer was placed in the geometric centre of the silage mass. The containers were covered with two layers of sterile cheese cloth to minimize drying, kept at room temperature $\left(25^{\circ} \mathrm{C}\right)$ and the temperature was measured at 2-h intervals.

Data, for chemical composition and fermentation characteristics of the silage, were analyzed in a completely randomized design (CRD), using the GLM procedure of SAS (2003). In vivo data were analyzed using the MIXED procedure of SAS (2003). The fixed effects of treatment and period, and the random effects of square and cow within a square were included in the model. For all variables the sampling was repeated over time (dry matter intake (DMI), milk yield and milk composition). The effect of time was included in the REPEATED statement of the model. The compound symmetric covariance structure was selected, based on the lowest Akaike Information Criterion (AIC). All differences were declared significant if $P<0.05$ and trends were discussed at $P<0.10$. 


\section{Results and Discussion}

The chemical composition and fermentation characteristics of pre-ensiled whole-crop maize and experimental silages are shown in Table 1. Ensiling increased $(P<0.05)$ the concentration of NDF and ADF, while reducing that of $\mathrm{DM}$, WSC, $\mathrm{CP}$ and the $\mathrm{pH}$, compared with the fresh maize crop. The concentration of lactic acid $(P<0.01)$ and acetic acid $(P<0.05)$ increased with inoculation compared to the control. The results are in agreement with Filya (2003a) and Kleinschmit \& Kung (2006c), who reported a greater concentration of lactic and acetic acid in maize silages in response to L. buchneri or L. buchneri $+L$. plantarum. In general, a high content of lactic acid was expected in the silages due to the high concentration of WSC in maize crops. This is confirmed by the substantial lower levels of residual WSC in the silages compared with that found in the respective fresh maize forages. The concentration of butyric acid was increased $(P<0.01)$ in response to inoculation with LM due to the heterofermentative activity of L. buchneri.

Table 1 Chemical composition and fermentation characteristics of pre-ensiled and ensiled maize $(n=3)$

\begin{tabular}{|c|c|c|c|c|c|}
\hline \multirow{2}{*}{ Item } & \multirow{2}{*}{ Fresh crop } & \multicolumn{2}{|c|}{ Maize silage } & \multirow{2}{*}{ SE } & \multirow{2}{*}{$P$ value } \\
\hline & & Control & LM & & \\
\hline Dry matter $(\mathrm{DM})(\mathrm{g} / \mathrm{kg})$ & 253.1 & 225.4 & 223.2 & 2.77 & 0.38 \\
\hline Organic matter (g/kg DM) & 921.5 & 903.3 & 898.8 & 9.58 & 0.59 \\
\hline Crude protein (g/kg DM) & 95.1 & 81.0 & 82.7 & 1.28 & 0.18 \\
\hline NDF (g/kg DM) & 468.5 & 587.7 & 598.4 & 4.88 & 0.05 \\
\hline $\mathrm{ADF}(\mathrm{g} / \mathrm{kg} \mathrm{DM})$ & 258.1 & 322.8 & 349.8 & 4.86 & 0.01 \\
\hline $\mathrm{pH}$ & 5.83 & 3.72 & 3.91 & 0.03 & 0.01 \\
\hline WSC (g/kg DM) & 118.0 & 53.2 & 52.4 & 2.06 & 0.66 \\
\hline Lactic acid (g/kg DM) & & 131 & 157 & 3.60 & 0.01 \\
\hline Acetic acid (g/kg DM) & & 13.3 & 15.9 & 1.07 & 0.04 \\
\hline Lactic acid/Acetic acid & & 9.88 & 9.92 & 0.61 & 0.93 \\
\hline Butyric acid (g/kg DM) & & 0.11 & 0.14 & 0.01 & 0.01 \\
\hline Propionic acid, (g/kg DM) & & 0.13 & 0.12 & 0.02 & 0.67 \\
\hline $\mathrm{NH}_{3}-\mathrm{N}(\mathrm{g} / \mathrm{kg} \mathrm{N})$ & & 6.73 & 5.67 & 0.37 & 0.03 \\
\hline Aerobic stability (h) & & 175 & 178 & 2.35 & 0.19 \\
\hline
\end{tabular}

NDF - neutral detergent fibre; ADF - acid detergent fibre; WSC - water-soluble carbohydrate.

LM - Lactisil Maize; SE - standard error.

Both silages, with and without inoculants, had good fermentation qualities, and the $\mathrm{pH}$ in both the control and Lactisil Maize treatment was below 4. Although a greater concentration of lactic acid was found in Lactisil Maize-silage, a higher $\mathrm{pH}(P<0.01)$ was recorded compared to the control. This may be partly related to a higher VFA concentration in these silages and a higher PKa value in VFA in comparison with lactic acid. Also, the results of previous studies have demonstrated greater concentrations of 1,2-propanediol (Taylor \& Kung, 2002; Nishino et al., 2004; Kleinschmit \& Kung, 2006a), ethanol and mannitol (Taylor \& Kung, 2002; Kleinschmit \& Kung, 2006a) in silages inoculated with L. buchneri, which may explain the higher $\mathrm{pH}$ of inoculated silages in the current study. In line with our study, silages with L. buchneri inoculants had a higher $\mathrm{pH}$ than the control or L. plantarum-inoculated silages in laboratory experiments conducted by Filya (2003b) and Kleinschmit \& Kung (2006c), and field studies by Mari et al. (2009) and Kristensen et al. (2010).

The lower $\mathrm{NH}_{3}-\mathrm{N}$ concentration in the Lactisil Maize-treated silage $(P<0.05)$ suggests that the inoculant reduced proteolysis, consistent with Filya (2003b) and Driehuis et al. (1999) who reported reduced $\mathrm{NH}_{3}-\mathrm{N}$ with $L$. buchneri $+L$. plantarum inoculation compared to untreated silages. Homofermentative bacteria such as L. plantarum usually accelerate the drop in $\mathrm{pH}$ at the beginning of ensiling (Weinberg \& 
Muck, 1996; Driehuis et al., 1997). McDonald et al. (1991) and Zahiroddini et al. (2004) reported that as soon as the silage $\mathrm{pH}$ falls rapidly after ensiling, the aerobic microorganisms and plant enzymes are inhibited, which results in reduced proteolysis.

Lactic acid and WSC are nutrient substrates for fungi and are consequently responsible for the aerobic deterioration of silages (McDonald et al., 1991; Ohmomo et al., 2002). On the other hand, the antifungal effects of acetic acid on fungus are well documented (Kung \& Ranjit, 2001; Nishino et al., 2003; Weinberg et al., 2011). In the current study, both lactic and acetic acid concentrations were increased $(P<0.05)$ with Lactisil Maize inoculation compared to the control, but the ratios of lactic to acetic acid were similar between treatments. Moreover, low levels of acetic acid $(<20 \mathrm{~g} / \mathrm{kg} \mathrm{DM})$ were found in Lactisil Maizeenriched silage and as a result, aerobic stability was not affected $(P>0.05)$ by the treatments.

The composition of the experimental diets, feed intake, ruminal fermentation, total tract nutrient digestibility and milk production data are shown in Tables 2 and 3. Cows fed inoculated silage had a lower $(P<0.05)$ DMI than those fed uninoculated silage. The reduced DMI with Lactisil Maize may have resulted

Table 2 Feed ingredients and chemical composition of the experimental diets $(\mathrm{n}=3)$

\begin{tabular}{|c|c|c|}
\hline & \multicolumn{2}{|c|}{ Treatment } \\
\hline & Control & Lactisil Maize \\
\hline \multicolumn{3}{|l|}{ Ingredients (g/kg DM) } \\
\hline Lucerne hay & 189.3 & 190.2 \\
\hline Maize silage & 230.4 & 228.8 \\
\hline Ground barley grain & 156.9 & 157.4 \\
\hline Ground maize grain & 117.1 & 117.7 \\
\hline Whole-linted cottonseed & 58.6 & 58.2 \\
\hline Canola meal & 38.8 & 39.1 \\
\hline Soybean meal & 137.7 & 137.2 \\
\hline Calcium soaps of fatty acids & 12.0 & 12.0 \\
\hline Fish meal & 8.1 & 8.1 \\
\hline Dried beet pulp & 27.2 & 27.6 \\
\hline Wheat bran & 8.1 & 8.1 \\
\hline Mineral and vitamin supplement & 12.0 & 12.0 \\
\hline Sodium bicarbonate chemical & 2.0 & 2.0 \\
\hline Calcium carbonate & 2.7 & 2.7 \\
\hline Salt & 3.2 & 3.2 \\
\hline \multicolumn{3}{|l|}{ Chemical composition ( $\mathrm{g} / \mathrm{kg} \mathrm{DM})$} \\
\hline Crude protein $(\mathrm{CP})$ & 183.0 & 183.0 \\
\hline Dry matter (DM) & 531.0 & 531.2 \\
\hline Organic matter $(\mathrm{OM})$ & 913.0 & 913.4 \\
\hline Acid detergent fibre (ADF) & 232.4 & 239.8 \\
\hline Neutral detergent fibre (NDF) & 398.7 & 406.9 \\
\hline Non-fibrous carbohydrate (NFC) & 284.3 & 276.5 \\
\hline Ether extract (EE) & 47.0 & 47.0 \\
\hline Calcium & 7.0 & 7.0 \\
\hline Phosphorus & 4.0 & 4.0 \\
\hline $\mathrm{NE}_{\mathrm{L}}(\mathrm{MJ} / \mathrm{kg} \mathrm{DM})$ (calculated) & 7.19 & 7.19 \\
\hline
\end{tabular}


Table 3 Dry matter intake, animal performance and apparent total tract nutrient digestibility $(\mathrm{n}=3)$

\begin{tabular}{|c|c|c|c|c|}
\hline \multirow{2}{*}{ Item } & \multicolumn{2}{|c|}{ Treatments } & \multirow{2}{*}{ SE } & \multirow{2}{*}{$P$ value } \\
\hline & Control & Lactisil Maize & & \\
\hline Dry matter intake $(\mathrm{kg} / \mathrm{d})$ & 26.0 & 25.2 & 0.70 & 0.03 \\
\hline Milk yield (kg/d) & 38.6 & 36.1 & 0.06 & 0.01 \\
\hline 4\% FCM yield $(\mathrm{kg} / \mathrm{d})$ & 34.9 & 31.9 & 0.95 & 0.01 \\
\hline Fat yield (kg/d) & 1.30 & 1.16 & 0.05 & 0.01 \\
\hline Protein yield, $\mathrm{kg} / \mathrm{d}$ & 1.19 & 1.10 & 0.05 & 0.01 \\
\hline Fat $\%$ & 3.39 & 3.26 & 0.17 & 0.16 \\
\hline Protein $\%$ & 3.08 & 3.03 & 0.07 & 0.07 \\
\hline Lactose $\%$ & 5.49 & 5.47 & 0.06 & 0.50 \\
\hline Body weight (kg) & 553 & 579 & 32.3 & 0.91 \\
\hline \multicolumn{5}{|l|}{ Ruminal $\mathrm{pH}$ and fermentation } \\
\hline $\mathrm{pH}$ & 6.12 & 6.18 & 0.13 & 0.45 \\
\hline Acetic acid (mol/100 mol) & 74.9 & 74.5 & 1.48 & 0.44 \\
\hline Propionic acid (mol/100 mol) & 17.2 & 18.3 & 1.76 & 0.56 \\
\hline Butyric acid (mol/100 mol) & 7.9 & 7.2 & 0.63 & 0.32 \\
\hline Acetic acid : propionic acid & 4.35 & 4.07 & 0.31 & 0.19 \\
\hline Total VFA (mmol/L) & 84.83 & 82.66 & 1.02 & 0.04 \\
\hline \multicolumn{5}{|l|}{ Digestibility, $\%$ of intake } \\
\hline Organic matter & 65.3 & 66.4 & 2.96 & 0.68 \\
\hline Crude protein & 64.3 & 63.8 & 2.74 & 0.78 \\
\hline Neutral detergent fibre & 53.4 & 54.1 & 1.47 & 0.35 \\
\hline
\end{tabular}

SE - standard error.

from the extensive fermentation and greater silage end-products (McAllister et al., 1998; Buxton et al., 2003). Moreover, Nishino et al. (2007) reported increased concentrations of biogenic amines (tyramine and putrescine) in maize silage treated with L. buchneri, which can limit DMI (Lingaas \& Tveit, 1992).

The reduced milk yield $(P<0.01)$ could be attributed to a decreased net energy intake due to the lower DMI in cows fed diets containing Lactisil Maize-inoculated silage. This was confirmed by a lower concentration of total VFA $(P<0.05)$ in the rumens of these cows. Furthermore, the reduced yields of milk fat and protein in cows fed the Lactisil Maize-inoculated silage were related to the lower actual milk yield as the levels of milk fat and protein were not affected $(P>0.05)$. Homofermentative LAB inoculants usually decrease milk fat and protein due to the high production of lactic acid and consequently decreasing the ratio of lipogenic VFAs (acetic acid and butyric acid) to glucogenic (propionate) VFAs (Huhtanen et al., 2003). The combination of homo- and heterofermentative LAB, in this study, produced milk with a similar $(P$ $>0.05)$ composition compared to the control. This can be partially explained by the similarity in molar proportions of the VFA in the rumen and the similar ratio of lipogenic VFA to glucogenic VFA. The lack $(P$ $>0.05$ ) of significant effects in treatment on the chemical composition of maize silage, confirms the similarity in the total tract, apparent digestibility of nutrients and molar proportion of VFA in the rumen content between the two cow groups. The lack of effects in the Lactisil Maize-inoculated silage treatment, on total digestibility of nutrients, is in agreement with other reports (Kung et al., 1990; McAllister et al., 1998; Filya, 2003a).

\section{Conclusion}

The inoculation of high-moisture maize with Lactisil Maize had no effect on the chemical composition of the silage, but altered the fermentation characteristics. Inoculated silages had greater concentrations of 
lactic acid and acetic acid, and less ammonia $\mathrm{N}$ compared to the control. Cows fed diets containing Lactisil Maize-inoculated silage consumed less feed and consequently produced less milk, whereas nutrient digestibility and milk composition were not affected. These results indicated that inoculating with dualpurpose LAB inoculants in high-moisture maize silage improved only the fermentation quality of the silage, while cow performance, feed efficiency and milk composition were not affected.

\section{Acknowledgements}

The authors wish to acknowledge the financial support from Isfahan University of Technology (Isfahan, Iran). The authors appreciate the assistance of the employees of the Lavark Research Station (Isfahan University of Technology) for animal care.

\section{References}

Aksu, T., Baytok, E. \& Bolat, D., 2004. Effects of a bacterial silage inoculant on corn silage fermentation and nutrient digestibility. Small Rumin. Res. 55, 249-252.

Allen, M.S., Coors, J.G. \& Roth, G.W., 2003. Corn silage. In: Silage Science and Technology. Agronomy Monograph 42. Eds. Buxton, D.R., Muck, R.E. \& Harrison, J.H., Amer. Soc. Agron. Crop Sci. Madison, WI, USA. pp. 547-608.

AOAC, 1990. Official Methods of Analysis. (15th ed.). Association of Official Analytical Chemists, Arlington, VA, USA.

Bal, M., Shaver, R., Al-Jobeile, H., Coors, J. \& Lauer, J., 2000. Corn silage hybrid effects on intake, digestion, and milk production by dairy cows. J. Dairy Sci. 83, 2849-2858.

Barker, B. \& Summerson, W.H., 1941. The colorimetric determination of lactic acid in biological material. J. Biol. Chem. 138, 535-554.

Buxton, R., Muck, R.E. \& Harrison, J., 2003. Silage Science and Technology. American Society of Agronomy, Inc. Crop Science Society of America, Inc., Soil Science Society of America, Inc. Madison, Wiscosin, USA.

Driehuis, F., Van Wikselaar, P.G., Van Vuuren, A.M. \& Spoelstra, S.F., 1997. Effect of a bacterial inoculant on rate of fermentation and chemical composition of high dry matter grass silages. J. Agric. Sci. 128, 323-329.

Driehuis, F., Elferink, S. \& Spoelstra, S., 1999. Anaerobic lactic acid degradation during ensilage of whole crop maize inoculated with Lactobacillus buchneri inhibits yeast growth and improves aerobic stability. J. Appl. Microbiol. 87, 583-594.

Dubois, M., Gilles, K.A., Hamilton, J.K., Rebers, A. \& Smith, F.F., 1956. Colorimetric method for determination of sugars and related substances. Anal. Chem. 28, 350-356.

Filya, I., 2001. Aerobic stability of sorghum and maize silages treated with homofermentative and heterofermentative lactic acid bacteria. Proceedings of the Turkey-Israeli Workshop on Silage and Agricultural By-Products for High Lactating Cows. pp. 24-26.

Filya, I., 2003a. The Effect of Lactobacillus buchneri and Lactobacillus plantarum on the fermentation, aerobic stability and ruminal degradability of low dry matter corn and sorghum silages. J. Dairy Sci. $86,3575-3581$.

Filya, I., 2003b. The effect of Lactobacillus buchneri, with or without homofermentative lactic acid bacteria, on the fermentation, aerobic stability and ruminal degradability of wheat, sorghum and maize silages. J. Appl. Microbiol. 95, 1080-1086.

Filya, I., Ashbell, G., Hen, Y. \& Weinberg, Z., 2000. The effect of bacterial inoculants on the fermentation and aerobic stability of whole crop wheat silage. Anim. Feed Sci. Technol. 88, 39-46.

Hu, W., Schmidt, R.J., McDonell, E.E., Klingerman, C.M. \& Kung Jr., L., 2009. The effect of Lactobacillus buchneri 40788 or Lactobacillus plantarum MTD-1 on the fermentation and aerobic stability of corn silages ensiled at two dry matter contents. J. Dairy Sci. 92, 3907-3914.

Huhtanen, P., Nousiainen, J., Khalili, H., Jaakkola, S. \& Heikkilä, T., 2003. Relationships between silage fermentation characteristics and milk production parameters: analyses of literature data. Livest. Prod. Sci. 81, 57-73.

Khorvash, M., Colombatto, D., Beauchemin, K.A., Ghorbani, G.R. \& Samei, A., 2006. Use of absorbants and inoculants to enhance the quality of corn silage. Can. J. Anim. Sci. 86, 97-107. 
Kleinschmit, D.H. \& Kung Jr., L., 2006a. The effects of Lactobacillus buchneri 40788 and Pediococcus pentosaceus R1094 on the fermentation of corn silage. J. Dairy Sci. 89, 3999-4004.

Kleinschmit, D.H. \& Kung Jr., L., 2006b. A meta-analysis of the effects of Lactobacillus buchneri on the fermentation and aerobic stability of corn and grass and small-grain silages. J. Dairy Sci. 89, 40054013.

Kowsar, R., Ghorbani, G., Alikhani, M., Khorvash, M. \& Nikkhah, A., 2008. Corn silage partially replacing short alfalfa hay to optimize forage use in total mixed rations for lactating cows. J. Dairy Sci. 91, 4755-4764.

Kristensen, N.B., Sloth, K.H., Hojberg, O., Spliid, N.H., Jensen, C. \& Thogersen, R., 2010. Effects of microbial inoculants on corn silage fermentation, microbial contents, aerobic stability, and milk production under field conditions. J. Dairy Sci. 93, 3764-3774.

Kung Jr., L. \& Ranjit, N., 2001. The effect of Lactobacillus buchneri and other additives on the fermentation and aerobic stability of barley silage. J. Dairy Sci. 84, 1149-1155.

Kung Jr., L., Carmean, B. \& Tung, R., 1990. Microbial inoculation or cellulase enzyme treatment of barley and vetch silage harvested at three maturities1. J. Dairy Sci. 73, 1304-1311.

Lingaas, F. \& Tveit, B., 1992. Etiology of acetonemia in Norwegian cattle. 2. Effect of butyric acid, valeric acid and putrescine. J. Dairy Sci. 75, 2433-2439.

Mari, L.J., Schmidt, R.J., Nussio, L.G., Hallada, C.M. \& Kung Jr., L., 2009. An evaluation of the effectiveness of Lactobacillus buchneri 40788 to alter fermentation and improve the aerobic stability of corn silage in farm silos. J. Dairy Sci. 92, 1174-1176.

McAllister, T.A., Feniuk, R., Mir, Z., Mir, P., Selinger, L.B. \& Cheng, K.J., 1998. Inoculants for alfalfa silage: Effects on aerobic stability, digestibility and the growth performance of feedlot steers. Livest. Prod. Sci. 53, 171-181.

McDonald, P., Henderson, A. \& Heron, S., 1991. The Biochemistry of Silage. $2^{\text {nd }}$ ed. Chalcombe Publications, Buckinghamshire, UK. 340 pp.

Muck, R., 1996. A lactic acid bacteria strain to improve aerobic stability of silages. In: US Dairy Forage Research Center, 1996 Research Summaries. Madison, WI: US Dairy Forage Research Center. pp. 42-43.

Muck, R.E., 2008. Improving alfalfa silage quality with inoculants and silo management. In: Proceedings of the 70th Annual Cornell Nutrition Conference for Feed Manufacturers. Syracuse, NY: Cornell University. pp. 137-146.

Nikkhah, A., Alikhani, M. \& Amanlou, H., 2004. Effects of feeding ground or steam-flaked broom sorghum and ground barley on performance of dairy cows in midlactation. J. Dairy Sci. 87, 122-130.

Nishino, N., Yoshida, M., Shiota, H. \& Sakaguchi, E., 2003. Accumulation of 1, 2 propanediol and enhancement of aerobic stability in whole crop maize silage inoculated with Lactobacillus buchneri. J. Appl. Microbiol. 94, 800-807.

Nishino, N., Wada, H., Yoshida, M. \& Shiota, H., 2004. Microbial counts, fermentation products, and aerobic stability of whole crop corn and a total mixed ration ensiled with and without inoculation of Lactobacillus casei or Lactobacillus buchneri. J. Dairy Sci. 87, 2563-2570.

Nishino, N., Hattori, H., Wada, H. \& Touno, E., 2007. Biogenic amine production in grass, maize and total mixed ration silages inoculated with Lactobacillus casei or Lactobacillus buchneri. J. Appl. Microbiol. 103, 325-332.

NRC, 2001. Nutrient requirements of dairy cattle, 7th rev. edn. Nat. Acad. Sci., Washington, D.C., USA.

Ohmomo, S., Tanaka, O., Kitamoto, H. \& Cai, Y., 2002. Silage and microbial performance, old story but new problems. Japan Agric. Res. Quarterly 36, 59-72.

SAS, 2003. SAS/STAT® User's Guide. SAS Institute Inc., Cary, N.C., USA.

Sheperd, A.C., Maslanka, M., Quinn, D. \& Kung Jr., L., 1995. Additives containing bacteria and enzymes for alfalfa silage. J. Dairy Sci. 78, 565-572.

Taylor, C.C. \& Kung Jr., L., 2002. The effect of Lactobacillus buchneri 40788 on the fermentation and aerobic stability of high moisture corn in laboratory silos. J. Dairy Sci. 85, 1526-1532.

Torriani, S., Dellaglio, F., Palummeri, M., Coscia, L. \& Baetens, M., 1992. Detection and characterization of epiphytic lactic acid bacteria on growing plants of maize [Zea mays L.] and lucerne [Medicago sativa L.][with relationship with animal feeding]. Annali di Microbiologia ed Enzimologia (Italy). 
Van Soest, P.J., Robertson, J.B. \& Lewis, B.A., 1991. Methods for dietary fibre, neutral detergent fibre, and nonstarch polysaccharides in relation to animal nutrition. J. Dairy Sci. 74, 3583-3597.

Weinberg, Z.G. \& Muck, R.E., 1996. New trends and opportunities in the development and use of inoculants for silage. FEMS Microbiol. Rev. 19, 53-68.

Weinberg, Z., Ashbell, G., Hen, Y. \& Azrieli, A., 1993. The effect of applying lactic acid bacteria at ensiling on the aerobic stability of silages. J. Appl. Microbiol. 75, 512-518.

Weinberg, Z., Ashbell, G., Hen, Y., Azrieli, A., Szakacs, G. \& Filya, I., 2002. Ensiling whole-crop wheat and corn in large containers with Lactobacillus plantarum and Lactobacillus buchneri. J. Indust. Microbiol. Biotechnol. 28, 7-11.

Weinberg, Z.G., Khanala, P., Yildiz, C., Chena, Y. \& Arieli, A., 2010. Effects of stage of maturity at harvest, wilting and LAB inoculant on aerobic stability of wheat silages. Anim. Feed Sci. Technol. 158, 29-35.

Weinberg, Z.G., Khanal, P., Yildiz, C., Chen, Y. \& Arieli, A., 2011. Ensiling fermentation products and aerobic stability of corn and sorghum silages. Grassl. Sci. 57, 46-50.

Zahiroddini, H., Baah, J., Absalom, W. \& McAllister, T.A., 2004. Effect of an inoculant and hydrolytic enzymes on fermentation and nutritive value of whole crop barley silage. Anim. Feed Sci. Technol. $117,317-330$. 